\title{
Arctic System Reanalysis improvements in topographically-forced winds near Greenland
}

\author{
G. W. K. Moore ${ }^{1^{*}}$, David H. Bromwich ${ }^{2,3}$, Aaron B. Wilson ${ }^{2}$, \\ Ian Renfrew ${ }^{4}$, Lesheng Bai ${ }^{2}$ \\ ${ }^{1}$ Department of Physics, University of Toronto, Toronto, Ontario, Canada \\ ${ }^{2}$ Polar Meteorology Group, Byrd Polar and Climate Research Center, \\ The Ohio State University, Columbus, Ohio, USA \\ ${ }^{3}$ Atmospheric Sciences Program, Department of Geography, \\ The Ohio State University, Columbus, Ohio, USA \\ ${ }^{4}$ School of Environmental Sciences, University of East Anglia, \\ Norwich, United Kingdom \\ Revised Manuscript submitted to QJRMS \\ March 24, 16
}
This article has been accepted for publication and undergone full peer review but has not been through the copyediting, typesetting, pagination and proofreading process, which may lead to differences between this version and the Version of Record. Please cite this article as doi: 10.1002/qj.2798

This article is protected by copyright. All rights reserved. 
Abstract: Southern Greenland is home to a number of weather systems characterized by high speed low-level winds that are the result of topographic flow distortion. These systems include tip jets, barrier winds and katabatic flows. Global atmospheric reanalyses have proven to be important tools in furthering our understanding of these systems and their role in the climate system. However, there is evidence that their mesoscale structure may be poorly resolved in these global products. Here output from the regional Arctic System Reanalysis (ASRv1-30 km and ASRv2-15 km grid resolutions) are compared to the global ERA-Interim Reanalysis (ERA-I-80 km grid resolution), focusing on their ability to represent winds in the vicinity of southern Greenland. Comparisons are made to observations from surface and upper-air stations, as well as from research aircraft flights during the Greenland Flow Distortion Experiment (GFDex). The ERA-I reanalysis has a tendency to underestimate high wind speeds and overestimate low wind speeds, which is reduced in ASRv1 and nearly eliminated in ASRv2. In addition, there is generally a systematic reduction in the root mean square error between the observed and the reanalysis wind speeds from ERA-I to ASRv1 to ASRv2, the exception being low-level marine winds where the correspondence is similar in all reanalyses. Case studies reveal that mesoscale spatial features of the wind field are better captured in ASRv2 as compared to the ERA-I or ASRv1. These results confirm that a horizontal grid size on the order of $15 \mathrm{~km}$ is needed to characterize the impact that Greenland's topography has on the regional wind field and climate. However even at this resolution, there are still features of the wind field that are under-resolved.

This article is protected by copyright. All rights reserved. 


\section{1) Introduction}

\subsection{Southern Greenland Wind Regimes}

The seas surrounding southern Greenland (Figure 1) are the windiest areas of the world ocean (Sampe and Xie 2007). The gale force winds that occur in this region can be broadly classified as westerly or easterly tip jets (Doyle and Shapiro 1999; Moore 2003), northeasterly barrier winds (Moore and Renfrew 2005), or northwesterly katabatic winds (Rasmussen 1989). The dynamics behind these weather systems share a common factor, flow distortion resulting from the interaction of extra-tropical cyclones with the high and steep topography of Greenland (Moore 2003; Moore and Renfrew 2005; Outten et al. 2009; Harden et al. 2011; Oltmanns et al. 2014).

In addition to their role in regional weather (Rasmussen 1989; Renfrew et al. 2008; Oltmanns et al. 2014), these systems are also important, for a variety of reasons, in the local and global climate. For example, the high winds associated with these systems have been argued to play a role in soil erosion in southern Greenland as well as contributing to the sourcing of atmospheric dust across the region (Silva-Sánchez et al. 2015), a process that may contribute to the darkening of and subsequent acceleration of mass loss from the Greenland Ice Sheet (GIS) (Dumont et al. 2014). High wind speeds associated with westerly tip jets have also been shown to contribute to the large losses of ocean buoyancy that drives oceanic convection in the Irminger Sea, a process that is an important component of the Atlantic Meridional Overturning Circulation (Pickart et al. 2003; Våge et al. 2008) as well as contributing to the oceanic sequestration of anthropogenic carbon (Sabine et al. 2004).

Barrier winds have been argued to be an important contributor to regional shelffjord interactions that act to modulate the presence of warm Atlantic Water in the fjords 
along Greenland's southeast coast (Harden et al. 2014; Straneo and Cenedese 2015), a process that has been proposed to play a role in the retreat of the region's marine terminating glaciers (Howat et al. 2011). These winds also play an important role in oceanic mixed-layer development, currents and shelf-break volume fluxes along the Denmark Strait (Haine et al. 2009; Magaldi and Haine 2015).

The strong outflow associated with katabatic winds can result in the loss of the ice mélange, the mixture of ice bergs and sea ice that acts to inhibit calving, from the region's marine terminating glaciers thereby contributing to loss of mass from the GIS (Straneo and Heimbach 2013; Oltmanns et al. 2014). These winds can also advect sea ice away from the coast leading to the formation of biologically important coastal polynyas as well as leading to large losses of buoyancy in adjoining oceanic regions (Oltmanns et al. 2014).

All of these weather systems are mesoscale in nature with horizontal length scales on the order of $500 \mathrm{~km}$ or less (Heinemann and Klein 2002; Moore and Renfrew 2005; Petersen et al. 2009; Renfrew et al. 2009a). More generally, the complex topography of the region (Figure 1) results in small-scale variability in the surface wind field. For example, in the vicinity of Sermilik Fjord, there are two automatic weather stations that are only $16 \mathrm{~km}$ apart for which the correlation between the wind speeds during the winter is only 0.4 (Moore et al. 2015); while observations made in the 1930s by British and Norwegian expeditions to the Kangerdlugssuaq Fjord found katabatic winds with strong lateral gradients in wind speed that were assumed to be the result of topographic sheltering (Manley 1938).

\subsection{The Greenland Flow Distortion Experiment and Modeling Flow Distortion}

This article is protected by copyright. All rights reserved. 
Given the data sparse nature of the Greenland region and the importance of topographically forced flow on the regional weather and global climate, a field campaign known as the Greenland Flow Distortion Experiment (GFDex) was held in late February and early March 2007 to investigate this phenomenon (Renfrew et al. 2008). The primary asset was a BAE 146 instrumented research aircraft that was stationed at Keflavik, Iceland during the experiment (Renfrew et al. 2008). Enhanced radiosonde launches during periods of interest were also made from sites in the region, including three locations in southeast Greenland (Figure 1).

Case studies of easterly tip jet and barrier wind events observed during GFDex found that the limited-area version of the Met Office Unified Model operational in 2007 (version 6.1) with a horizontal resolution of $12 \mathrm{~km}$ was able to satisfactorily represent the structure and evolution of these weather systems, including the low-level characteristics of the observed regions of high wind speed, (Outten et al. 2009; Petersen et al. 2009). A detailed comparison of the low-level data collected during GFDex with operational analyses, reanalyses, both regional and global, as well as hindcasts indicated that a horizontal resolution below $\sim 25 \mathrm{~km}$ was required to adequately represent the observed spatial variability of the low-level wind field (Renfrew et al. 2009b). However such a resolution was a necessary but not sufficient condition as specifics of the atmospheric boundary layer and surface flux parameterizations used also had a significant impact on the fidelity of the representation of the surface wind field (Renfrew et al. 2009b).

DuVivier and Cassano (2013) used the Weather Research and Forecasting (WRF) limited area forecast model (Skamarock et al. 2008) to investigate the tip jet and barrier wind events observed during GFDex. For each case, the model was run at horizontal 
resolutions of 10,25, 50 and $100 \mathrm{~km}$ and the results compared against the corresponding observed low-level and dropsonde data. This approach has the advantage of controlling for the specifics of the model's parameterizations identified as an issue by Renfrew et al. (2009b). In general, the $10 \mathrm{~km}$ model runs were better able to capture the maxima in the observed low-level wind speeds; for example the $25 \mathrm{~km}$ runs underestimated the maximum low-level wind speed during the easterly tip jet event by $5-11 \%$ as compared to the $10 \mathrm{~km}$ model (DuVivier and Cassano 2013). For the barrier wind event, the root mean square error between the observed and model wind speeds for the $10 \mathrm{~km}$ and $25 \mathrm{~km}$ model runs were both $\sim 1.5 \mathrm{~m} \mathrm{~s}^{-1}$, while that for the $50 \mathrm{~km}$ model run was $\sim 2.6 \mathrm{~m} \mathrm{~s}^{-1}$ suggesting that, in agreement with Renfrew et al (2009b), a resolution below $\sim 20-25 \mathrm{~km}$ is needed to resolve the mesoscale variability of tip jets and barrier wind events in the vicinity of southeast Greenland.

It is clear that representations of the wind field with grid spacing sufficient to resolve the mesoscale nature of these weather systems is needed if one is to fully characterize their structure and role in the climate system (Hamilton 2008). For example, Jung et al. (2014) showed that when an ocean model was forced by atmospheric fields that retain variability on the mesoscale, the strength of wind-driven gyres in the North Atlantic as well as the Atlantic Meridional Overturning Circulation was increased by 5$10 \%$ as compared to that when forced by synoptic-scale atmospheric variability alone.

In discussions of the ability of a model to capture mesoscale variability, one must distinguish between its horizontal grid resolution and the horizontal scale at which it can represent features of the atmospheric flow (Skamarock 2004). One widely used diagnostic is to evaluate the power spectrum of the low-level kinetic energy and identify 
the length scale at which the slope of the spectrum deviates from theoretical or observed spectra, with this length scale indicating the "effective resolution" (Skamarock 2004). Typically this divergence occurs at a length scale that is 5-7 times the horizontal resolution (Skamarock 2004; Condron and Renfrew 2013; Moore et al. 2015), with some variation depending on model configuration. Using this metric, the effective resolution of ERA-Interim (the current global reanalysis product from ECMWF which has a horizontal grid size of $\sim 80 \mathrm{~km}$ (Dee et al. 2011)) is only $\sim 400 \mathrm{~km}$, implying that this global reanalysis product will under-resolve the mesoscale (typically $100-500 \mathrm{~km}$ scale) features discussed above. So although ERA-I has proven important in characterizing flows around Greenland (Harden et al. 2011; Moore 2012; Oltmanns et al. 2014), it is clear that the mesoscale characteristics of these weather systems will be under-resolved by such global products.

\subsection{Arctic System Reanalysis}

The need for a high resolution representation of the structure and variability of the Arctic troposphere is not of course limited to southeast Greenland and it was for this reason that the Arctic System Reanalysis (ASR), a regional reanalysis of the Arctic region was initiated (Bromwich et al. 2015). The ASR uses a version of WRF adapted for use in polar regions (Hines et al. 2015). At present, 2 versions of the ASR exist, a 30 $\mathrm{km}$ grid size version known as ASRv1 and a $15 \mathrm{~km}$ grid size version known as ASRv2, with effective horizontal resolutions of $\sim 200$ and $\sim 100 \mathrm{~km}$ respectively. The ASR has $\sim 26$ levels below $1 \mathrm{~km}$ as compared to the $\sim 10$ levels in the ERA-I. This increased vertical resolution should result in an improved representation of boundary processes in the ASR. 
During 2007, it was found that the ASRv1 and ERA-I had similar annual mean biases in surface and $500 \mathrm{hPa}$ fields with the ASRv1 generally having smaller root mean square errors and higher correlations (Bromwich et al. 2015). In agreement with the above, Moore et al. (2015) found that the higher resolution ASRv1 product was able to resolve mesoscale features of wind events in southeast Greenland better than the ERA-I. Although, somewhat paradoxically, ERA-I had a lower root mean square error in the 10 $\mathrm{m}$ wind speed at the Tasiilaq station, situated outside of the Sermilik Fjord (Figure 1). This was attributed to the inability of the ERA-I to represent the downslope acceleration associated with mountain waves triggered over the steep topography to the north of the site during barrier wind events (Harden and Renfrew 2012). The ASRv1 was able to represent this process, but not the sheltering of the site from the winds by the complex local topography leading to higher wind speeds at Tasiilaq as compared to the ERA-I and the observations.

In this paper, we will merge the aforementioned research strands that have previously studied either the offshore structure of these topographically forced winds using the GFDex dataset (Outten et al. 2009; Petersen and Renfrew 2009; Petersen et al. 2009; Renfrew et al. 2009b; DuVivier and Cassano 2013) or their onshore expression using observations from Greenland (Oltmanns et al. 2014; Moore et al. 2015). To account for the documented need for high horizontal resolution, while controlling for biases introduced by model parameterizations, we will compare and contrast the ability of the ERA-I to represent these weather systems with the ASRv1 and ASRv2.

\section{2) Data}

This article is protected by copyright. All rights reserved. 
In-situ observations from Greenland are generally limited to coastal sites maintained by the Danish Meteorological Institute (DMI). Hourly data is available from 6 surface stations along the southeast coast of Greenland (Figure 1 and Table 1). In addition, there are 3 upper-air sites in the region (Figure 1 and Table 1) where data is available on a twice daily basis ( 00 UTC and 12 UTC). For specific cases during GFDex, additional upper-air data is available at 06 UTC and 18 UTC (Renfrew et al. 2008).

Six of the 12 research flights during GFDex collected data on the low-level wind field in the vicinity of southeast Greenland. These included a flight (B268) into an easterly tip jet (Renfrew et al. 2009a), 4 flights (B274, B276, B277 and B278) into an evolving barrier wind event (Petersen et al. 2009) and one flight (B271) into a polar low over the Iceland Sea (Renfrew et al. 2008). These flights were typically organized into a high-level component, during which dropsondes were deployed to investigate the vertical structure of the system, as well as a low-level component, typically flown at heights of $\sim 30 \mathrm{~m}$ above sea-level, to sample the weather system's surface expression (Renfrew et al. 2008). The low-level data that will be used in this paper were quality controlled and processed into 2 minute long 'runs' in which the wind speed data were adjusted to a height of $10 \mathrm{~m}$ using stability-dependent surface-layer similarity theory - see Petersen and Renfrew (2009b) and Renfrew et al. (2009b). The dropsonde data were uploaded in real time to the Global Telecommunications System and as such, were assimilated into the ERA-I and the ASR. Please refer to Table 2 for additional details on these research flights and Renfrew et al. (2008) for the flight tracks.

We will compare these observations with winds from ERA-I and the two ASR products during the period 15 February to 16 March 2007 . The two reanalyses are the 
result of very different data assimilation systems and underlying numerical models with differing numerical cores, parameterizations and resolutions. For example, ERA-I is based on a global spectral model and a highly-advanced 4D variational data assimilation scheme; while the ASR is based on a regional gridpoint model and a 3D variational data assimilation scheme that is optimized for use at high latitudes (Dee et al. 2011; Bromwich et al. 2015). Among the optimizations included in the ASR are the use of a land-surface scheme that includes fractional sea ice cover with variable thickness and snow cover as well as an improved representation of the albedo of snow and ice (Bromwich et al. 2015; Hines et al. 2015). The ERA-I data is available on a 6-hourly basis, while that from the ASR is available on a 3-hourly basis. However unless otherwise noted, the ASR data was subsampled to a 6-hourly basis.

For the comparison with the surface stations, the gridded 6-hourly ERA-I and ASR data were linearly interpolated to the location of each station. A similar approach was used for the data from the radiosonde sites. In addition, both the radiosonde and reanalysis data were interpolated to a common vertical grid with a spacing of $100 \mathrm{~m}$. The aircraft data, both the low-level and dropsonde data, are available at irregular time intervals and the decision was made to interpolate the ERA-I and ASR data both temporally and spatially to the location and time that the observations were made. In this instance, the 3-hourly ASR data were used. However a comparison with the results when the ASR data was subsampled to 6 hours indicated no significant differences.

\section{Results}

Figure 1 shows the topography of the region of interest as represented in the ERA-I, ASRv1 and ASRv2. The ERA-I is able to capture the large-scale characteristics 
including the high topography of the South and North Domes as well as the steep coastal topography along Greenland's southeast coast. However, in comparison to the ASRv1 and ASRv2, it is clear that the coastal gradients are under-resolved as are the topographic ridges to the north of the Sermilik and Kangerdlugssuaq Fjords. In particular, the ASRv2 is able to resolve the high topography along the ridge to the north of Sermilik Fjord that contains Mount Forel, the highest point in Greenland. In addition, unlike the lower resolution topographies, the ASRv2 topography is able to resolve the catchment areas of the Køge Bugt, Sermilik and Kangerdlugssuaq Fjords that play an important role in channeling the katabatic winds that develop along these fjords (Rasmussen 1989; Oltmanns et al. 2015).

Figure 2 shows the mean $10 \mathrm{~m}$ wind speed and direction for the period 15 February - 16 March 2007 as represented in the ERA-I, ASRv1 and ASRv2. All three reanalyses capture the enhanced barrier flow along the Denmark Strait as well as northeasterly flow in the vicinity of Cape Farewell that result from the anomalous southeastward position of the Iceland Low during this period (Moore et al. 2011). The magnitude of the wind speeds tends to increase with increasing horizontal resolution, a result consistent with DuVivier and Cassano (2013). In addition, the ASRv1 and ASRv2 representations include an enhanced gradient in wind speed along the ice edge. Along the coast, the ASR representations include regions of low wind speed downwind of the Sermilik and Kangerdlugssuaq Fjords, absent from the ERA-I, that were previously proposed to be the result of sheltering (Moore et al. 2015). In the vicinity of Cape Farewell, the ASR representations include a hitherto unseen onshore extension of the region of high wind speeds that is most resolved in the ASRv2. Along the southeast 
coast of Greenland, there is an increasing degree of fine scale structure as one goes from the ERA-I to the ASRv2. For example, onshore of Scoresby Sund, in a region of complex topography (Fig 1), the wind field is relatively homogeneous in the ERA-I representation but takes on a much more complex representation in the ASRv2.

Figure 3 shows time series of the $10 \mathrm{~m}$ wind speed at the DMI sites along with the corresponding values from the three reanalyses during the GFDex period, while Table 3 shows the relevant statistics. The northernmost station (Ittoqqortoormiit) is characterized by relatively low wind speeds during the first half of the period, while the two southernmost stations (Ikermiuarsuk \& Ikerasassuaq) have much higher wind speeds. During the second half of the period this is reversed. This is consistent with the synoptic conditions experienced during the field campaign (Renfrew et al. 2008). In agreement with Moore et al. (2015), the wind speeds at Ikermit were much higher than those at Tasiilaq. This is the result of Ikermit being exposed to katabatic flow down the Køge Bugt Fjord, while Tasiilaq is in a more sheltered location that does not feel the influence of katabatic flow down the Sermilik Fjord.

With respect to the GFDex cases of interest, the station closest to Cape Farewell, Ikerasassuaq, clearly experienced high winds during the easterly tip jet event that was investigated during flight B268. In agreement with the results presented in Figure 2, the ERA-I significantly underestimated the wind speed at this location during this event. In contrast, the two ASR products were in much better agreement with the ASRv2 having a slightly higher wind speed as compared to the observations and the ASRv1. The barrier wind flights (B274, B276, B277 and B278) all occurred during the period of elevated wind speeds at the northern site Ittoqqortoormiit. In particular, during flight B277, high 
winds were observed at this site that were associated with topographic flow distortion associated with the nearby Cape Tobin (Petersen et al. 2009). As was the case for the easterly tip jet, the ERA-I underestimated the wind speed at this site during this event as compared to the observations and the ASR products.

Køge Bugt Fjord is a site where strong katabatic winds are common and one such event, is identified as KF in Figure 3. At the adjacent DMI site at Ikermit, wind speeds in excess of $25 \mathrm{~m} \mathrm{~s}^{-1}$ were observed, again these were underestimated in the ERA-I and to a lesser extent in the ASRv1, in contrast to the wind speed in the ASRv2 which was indistinguishable from that observed. As discussed above, the Tasiilaq site is sheltered from both the offshore barrier flow and the katabatic flow from the nearby Sermilik Fjord resulting in a relatively benign wind climate. At this site, the ERA-I tended to overestimate the wind speed as compared to the ASR products, especially during periods when the observed wind speeds were low.

Table 3 presents the mean observed and reanalysis wind speeds as well as the root mean square errors, correlation coefficients and slopes of the least squares fits between the observations and reanalysis results. For each station and collectively, there is a reduction in the root mean square error and an increase in the correlation coefficient as well as a tendency for the regression slope to approach 1, during the transition from the ERA-I to ASRv1 to ASRv2. The only exception to a monotonic improvement in the statistics is at Tasiilaq (station 04360), where the correlation and slope are worse for ASRv1 than for ERA-I. As discussed by Moore et al. (2015), this is the result of the complex topography in the vicinity of the station that is not fully resolved by the ASRv1. However, it is clear that the ARv2 is better able to resolve the flow at this site. 
Figure 4 shows scatterplots of the $10 \mathrm{~m}$ wind speed data from the 5 reporting DMI sites with the corresponding values from the three reanalyses. Consistent with Table 3, there is a reduction of the spread between the observations and reanalysis results along with an increase in the regression slope between the ERA-I and ASRv2. As a result, the pronounced bias present in the ERA-I where low wind speeds are overestimated and high wind speeds are underestimated is significantly reduced in the ASRv2. There are still instances where the ASRv2 overestimates the wind speed in low-wind speed situations. It is thought that these are most likely the result of situations, like that identified by Moore et al. (2015), where the ASRv2 is unable to fully capture the sheltering by local topographic features.

Moving to the upper-air data, Figure 5 shows the mean observed vertical profile of wind speed, below $4 \mathrm{~km}$, at the three DMI radiosonde sites, Ittoqqortoormiit, Tasiilaq and Narsarsuaq, as well as those from the three reanalyses during the GFDex period. It should be emphasized that the radiosonde data were included in the data assimilation cycles at the ECMWF and in ASR, and therefore these data sets are not independent. With respect to the northernmost site, Ittoqqortoormiit, the vertical profiles from the three reanalysis product all show a pronounced low-level jet that is absent from the observations. The reasons for this are unclear, but Petersen et al. (2009) found that the operational UK Met Office analysis also failed to capture the observed boundary layer structure at this site during the GFDex barrier wind event. For the other two sites, the ASRv2 is better able to capture the observed mean vertical structure of the wind field as compared to the ASRv1 and ERA-I. Table 4 summarizes the error statistics of the lowlevel wind speed profile in the three reanalyses as compared to observations. Excluding 
Ittoqqortoormiit, there is a decrease in the root mean square error as well as an increase in the correlation coefficient and an increase in the slope of the least squares fit lines as one transitions from the ERA-I to the ASRv2. However in comparison with Table 3, the error statistics for the wind speed profiles are less skillful than those for the $10 \mathrm{~m}$ wind speed.

Turning now to the comparison with the GFDex data, we present in Figure 6 scatterplots of the $10 \mathrm{~m}$ wind speed observed during the low-level flight legs and the corresponding reanalysis values. It should be noted that unlike the comparison with the land-based observations (Figure 4), all three reanalyses had a consistent low wind speed bias across all observed wind speeds. With respect to the level of agreement, there was an improvement, i.e. a reduction in root mean square error and an increase in the correlation coefficient, between the ASRv1 and ASRv2 suggesting that the increase in resolution allowed for an improved representation of the spatial gradients in the low-level wind field during the GFDex flights. However the error statistics between the ERA-I and ASRv2 are quite similar, implying that for this data set, the higher grid resolution of ASRv2 has not improved the representation of the low-level wind speed. We suggest that, in agreement with Renfrew et al. (2009b), specifics of the underlying model's parameterizations also play a role in the representation of the low-level marine wind field associated with tip jets and barrier flow.

Table 5 provides wind speed error statistics below $4 \mathrm{~km}$ from the GFDex dropsonde comparison to the three reanalyses. With respect to the root mean square errors, there is typically a reduction in magnitude as one transitions from the ERA-I to the ASRv2. The correlation coefficients and regression slopes are similar between the three 
reanalyses, with the ASRv2 performing better in most cases. Figure 7, which shows the scatterplots of observed and reanalysis dropsonde wind speeds during the GFDex flights, confirms the characteristics of the error statistics presented in Table 5. Although not evident from the statistics, as a result of their low numbers, Figure 7 does show that the ASRv2 is better able to represent the cases where the wind speed is in excess of $40 \mathrm{~m} \mathrm{~s}^{-1}$ as compared to the ERA-I and ASRv1. Comparing the wind profile comparisons from GFDex (Figure 7, Table 5) to those at Tasillaq (Figure 5, Table 4), it is clear the reanalyses do a better job (lower root mean square errors and improved correlations) for the former and the improvement with resolution is smaller. Again we suggest that this is because the GFDex data are primarily marine locations, so improvements due to higher resolution are modest.

Having provided a number of more quantitative measures of the impact that resolution has on the ability of the three reanalyses to represent the observed low-level wind speed around southern Greenland, we will finish with a more qualitative comparison that is based on three events during the GFDex period. Figure 8 shows the sea-level pressure, $10 \mathrm{~m}$ wind and $10 \mathrm{~m}$ wind speed fields as represented by the three reanalyses during the easterly tip jet event sampled during flight B268 (Table 2). At this time, the parent synoptic-scale low was situated to the southeast of Cape Farewell (Renfrew et al. 2009a) and as a result, the region of interest was under the influence of northeasterly flow. All three reanalyses were able to capture the synoptic-scale pressure gradient associated with this system. The ERA-I had a broad region of high pressure over eastern portions of the GIS. In the ASR products, this feature was reduced to a mesoscale region of high pressure in the vicinity of the Køge Bugt Fjord, a result in agreement with 
the case study of this event (Outten et al. 2009). On the eastern side of Greenland, a ridge associated with this feature couples with a trough that extends along the west coast of Greenland towards Cape Farewell to enhance the pressure gradient that is associated with high wind speeds in the core of the tip jet. In the ASR products, the presence of a mesoscale low downwind of Cape Farewell results in an enhancement of gradient and the concomitant high winds in the vicinity of Cape Farewell. This feature is also present in the simulations of Outten et al. (2009).

One consequence of the presence of this mesoscale low in the ASR products is a region with a large horizontal pressure gradient that extends northwards from Cape Farewell towards the South Dome of the GIS (Figure 1). This gradient results in an onshore extension of the high wind speeds associated with the tip jet, a feature that is absent in the ERA-I. The gradient is stronger in the ASRv2 as are the wind speeds in the core of the jet. Indeed, there is an approximate $25 \%$ increase in the peak $10 \mathrm{~m}$ wind speed associated with the tip jet in the ASRv2 as compared to the ERA-I.

Details on the vertical structure of the tip jet and its onshore extension are provided in Figure 9. Consistent with Figure 8, ERA-I does not resolve the onshore extension of the tip jet in the vicinity of Narsarsuaq. The ASRv1 tends to overestimate its magnitude, most likely as a result of errors in the placement of the mesoscale low, while the ASRv2 is in good agreement. It should be noted that the Narsarsuaq observations indicated the presence of wind speed perturbations above $2 \mathrm{~km}$ that are most likely the result of gravity wave activity that are not captured in any of the reanalyses. The two dropsonde profiles were selected so as to provide information on the wind speed gradient on the eastern flank of the tip jet (Figure 8). Again the ERA-I and the ASRv1 
are unable to capture the high winds speeds in the core of the tip jet as represented in the 13:21 UTC dropsonde. In contrast, the ASRv2 does a much better job with a maximum wind speed of $\sim 46 \mathrm{~m} \mathrm{~s}^{-1}$ as compared to the observed maximum of $\sim 49 \mathrm{~m} \mathrm{~s}^{-1}$. This is in agreement with the results of Outten et al. (2009). On the eastern flank of the tip jet, all of the reanalyses underestimate the highest wind speeds, with the ERA-I and ASRv2 performing best.

Figure 10 shows the sea-level pressure, $10 \mathrm{~m}$ wind and $10 \mathrm{~m}$ wind speed fields as represented by the three reanalyses during the barrier wind event sampled during flight B277 (Table 2). The aircraft data were centered $~ 15$ UTC and so for this case the ERA-I data at 12 UTC and 18UTC were averaged to provide data at this time. For this event, the parent low was situated off the southeast coast of Iceland and the Denmark Strait region was under the influence of its synoptic-scale pressure gradient (Petersen et al. 2009). As was the case for the tip jet event, there is a region of high pressure over Greenland that takes on a more complex shape as one transitions from the ERA-I to the ASRv2. There is also a pressure trough along the southeast coast of Greenland extending southwards from Scoresby Sund towards Kangerdlugssuaq Fjord (Figure 1) that takes on higher-order structure in the ASR products that includes the presence of a mesoscale low downwind of Kangerdlugssuaq Fjord. Again, transitioning from the ERA-I to the ASRv2 results in an approximate $25 \%$ increase in the maximum $10 \mathrm{~m}$ wind speeds in the barrier flow. The 10 m wind speed distribution over the Denmark Strait can be seen to be an interplay between the mesoscale features of sea-level pressure field and the distribution of sea ice. As a result of its ability to capture the mesoscale structure of the sea-level pressure field, the 
ASRv2 contains a signature of the left-hand corner jet offshore of Cape Tobin, the most easterly point along the southeast coast of Greenland (Petersen et al. 2009).

Figure 11 shows wind speed profiles from the Ittoqqortoormiit radiosonde launch at 12 UTC along those from two dropsondes released during flight B277. As was found to be the case for the monthly mean vertical profiles, there is a significant disagreement between the observed and reanalysis wind speed profiles at Ittoqqortoormiit. In particular, all three reanalyses contain a representation of a low-level jet that is most likely associated with the feature seen in the vicinity of Cape Tobin at this time (Figure 10). Again, there is good agreement between the ERA-I and ASRv2 with respect to the maximum wind speed. Offshore, the 14:09 UTC dropsonde was situated in entrance region of the barrier flow that was situated over the marginal ice zone. All three reanalyses were able to capture the shallow nature of the jet at this time with the ASRv2 coming closest to the observed wind speed in the core of the jet. However all reanalyses underestimated the low-level wind speed. The 14:59 UTC dropsonde was located along the onshore flank of the barrier jet close to the ice edge. For this dropsonde, all three reanalyses under-estimate the maximum wind speed at this location, with the ERA-I and ASRv2 again coming close to the observed maximum. Unlike what occurred at the site of the 14:09 UTC dropsonde, all three reanalyses were in good agreement with the observations with respect to the low-level wind speeds below the jet core. In addition at this location, the ERA-I, unlike the ASR products, was unable to capture the strong vertical shear above the jet core. There is also evidence of gravity wave activity in both dropsondes that is absent from all the reanalyses. Wave-like features in the clouds were observed from the research aircraft during this event. 
We conclude with an example of a katabatic flow event. On 16 February 2007, the DMI station at Ikermit, offshore of the Køge Bugt Fjord (Figure 1) reported a $10 \mathrm{~m}$ wind speed in excess of $25 \mathrm{~m} \mathrm{~s}^{-1}$ (Figure 3d). We show in Figure 12 the sea-level pressure, $10 \mathrm{~m}$ wind and $10 \mathrm{~m}$ wind speed fields at 00 GMT on 16 February. At this time, the parent low was situated near $63^{\circ} \mathrm{N}, 25^{\circ} \mathrm{W}$. The ASR products capture the formation of a region of high pressure along the coast to the south of the fjord as well as a region of low pressure upwind of the fjord. As a result of these mesoscale features, there is an enhanced pressure gradient in the ASR products that results in strong outflow in the vicinity of the fjord that extends a considerable distance offshore. In this instance, the maximum 10 m wind speeds in the ERA-I are $\sim 12 \mathrm{~m} \mathrm{~s}^{-1}$ and $\sim 32 \mathrm{~m} \mathrm{~s}^{-1}$ in the ASRv2. Oltmanns et al. (2015) found a similar increase in wind speed with increasing horizontal resolution for a case study of katabatic flow within the Sermilik Fjord.

\section{Discussion}

Southern Greenland's high topography combined with its location along the primary North Atlantic storm track results in a number of low-level high wind speed weather systems that are the result of topographic flow distortion. The systems include tip jets, barrier winds and katabatic flow that all play important roles in regional weather and global climate. Given the remote and data sparse nature of the region along with its inhospitable weather, numerical models, including atmospheric reanalyses, have played a key role in the characterization of these systems and their impact. These systems all have mesoscale characteristics and there is evidence that global reanalyses such as the ERA-I, while providing much information on their structure, may under-resolve these characteristics. The recent availability of high resolution regional reanalyses of the Arctic 
as represented by the ASR provides a hitherto unavailable opportunity to more completely characterize these weather systems and their role in the climate system.

This study is unique in that it looks at both onshore and offshore representation of topographic flow distortion in the ERA-I and ASR using operational observations from DMI sites and GFDex observations. Previous work has identified the important role that differing model parameterizations have on the representation of these weather systems (Renfrew et al. 2009b) and the inclusion of both the $30 \mathrm{~km}$ ASRv1 and $15 \mathrm{~km}$ ASRv2 products allows for a partial control of this effect.

Increasing horizontal resolution improves the representation of the onshore structure of topographically forced flow in southeast Greenland as evidenced by an elimination of low and high wind speed biases, smaller root mean square errors, higher correlation coefficients and regression slopes closer to 1 for both the surface winds (Table 3; Figure 4) and the upper-level winds (Table 4; Figure 5). In contrast for the GFDex low-level flights, there was no appreciable difference between the error statistics for the ERA-I and ASR products (Figure 6). However, the GFDex dropsonde data did show a general improvement in the goodness of fit with observations between the ERA-I and the ASRv2. This suggests that increasing horizontal resolution does play a role in improving the representation of these weather systems but that the parameterization of marine boundary layer also plays an important role. There is also indirect evidence from the dropsonde data over the marginal ice zone (Figure 11b) that both the ERA-I and ASR may overestimate the surface roughness in this region.

In general, there was a $10-20 \%$ underestimation in peak winds speeds in tip jets, barrier winds and katabatic winds in the ERA-I as compared to the ASRv2. This is in 
agreement with previous work (DuVivier and Cassano 2013; Moore et al. 2015) and suggests that the impact of these weather systems, including the forcing of deep ocean convection, are under-resolved in the current generation of climate models that have a horizontal resolution on the order of $100 \mathrm{~km}$ (Kinter et al. 2012). Indeed, Jung et al (2014) showed a significant $10 \%$ increase in the strength of strength of surface and deep ocean currents when an ocean model was forced with atmospheric fields with a horizontal resolution of $40 \mathrm{~km}$ as compared to that when only synoptic-scale variability was retained. This suggests further impacts on the strength of the oceanic circulations can be expected from higher resolution representations of the forcing associated with these weather systems.

Global reanalyses with horizontal resolutions higher than that for ERA-I, such as the Climate Forecast System Reanalysis (Saha et al. 2010) with a horizontal resolution of $\sim 40 \mathrm{~km}$ and the JRA55 (Ebita et al. 2011) with a horizontal resolution of $\sim 50 \mathrm{~km}$, were also investigated with respect to their ability to represent orographic flow near Greenland. For both of these reanalyses, no systematic improvement over the ERA-I was found, and the comparisons against observations were qualitatively similar to the ERA-I.

New features of topographic flow distortion in southeast Greenland were also identified with the ASR products. Among these is an onshore extension of the high winds associated with the easterly tip jets (Figures $8 \& 9$ ). This region of high winds that extends from the South Dome to Cape Farewell was most apparent in the ASRv2. It appears to be associated with a mesoscale low that develops in the lee of Cape Farewell. Such lows have been predicted to develop as hydrostatic response to flow impinging on a topographic barrier (Smith 1982). Petersen et al. (2009) suggested that barrier flow along 
Greenland's southeast coast results in the formation of a 'corner' jet near Cape Tobin, the promontory near Scoresby Sund (Figure 1). The ASR reanalyses also show this jet and indicate that a horizontal resolution of $15 \mathrm{~km}$ is needed to fully represent it (Figure 10). The onshore $10 \mathrm{~m}$ wind field in the vicinity of Scoresby Sund also exhibits more complex spatial variability in the ASRv2 as compared to the ERA-I that is most likely the result of higher spatial resolution that can better represent the complex topographic and land-use gradients in this region. The Køge Bugt Fjord has been previously identified as a region where intense katabatic winds can develop (Moore et al. 2015). The ASRv2 provides additional information on the structure of this flow including an increase in the $10 \mathrm{~m}$ wind speed and an offshore region of elevated wind speeds.

\section{Acknowledgements}

This work was supported by the Natural Sciences and Engineering Research Council of Canada as well as the National Aeronautics and Space Administration (NASA) grant NNX12AI29G. The authors thank the Ohio Supercomputer Center (http://www.osc.edu) for their use of the Glenn, Oakley and Ruby Clusters in order to conduct the ASR. The authors would also like to acknowledge the participants in the Greenland Flow Distortion Flow Experiment whose data collection activities were central to this paper. This is Contribution 1543 of the Byrd Polar and Climate Research Center.

\begin{tabular}{|l|l|l|l|l|l|l|}
\hline Site & ID & Vicinity & Data & Latitude & Longitude & Elevation \\
\hline Ittoqqortoormiit & 04339 & Scoresby Sund & $\begin{array}{l}\text { Surface \& } \\
\text { Upper-Air }\end{array}$ & $70.48^{\circ} \mathrm{N}$ & $21.95^{\circ} \mathrm{W}$ & $65 \mathrm{~m}$ \\
\hline Aputiteeq & 04351 & Kangerdlugssuaq Fjord & none & $67.78^{\circ} \mathrm{N}$ & $32.30^{\circ} \mathrm{W}$ & $13 \mathrm{~m}$ \\
\hline Tasiilaq & 04360 & Sermilik Fjord & $\begin{array}{l}\text { Surface \& } \\
\text { Upper-Air }\end{array}$ & $65.60^{\circ} \mathrm{N}$ & $37.63^{\circ} \mathrm{W}$ & $36 \mathrm{~m}$ \\
\hline Ikermiit & 04373 & Køge Bugt Fjord & Surface & $64.78^{\circ} \mathrm{N}$ & $40.30^{\circ} \mathrm{W}$ & $85 \mathrm{~m}$ \\
\hline Ikermiuarsuk & 04382 & North of Cape Farewell & Surface & $61.93^{\circ} \mathrm{N}$ & $42.07^{\circ} \mathrm{W}$ & $39 \mathrm{~m}$ \\
\hline
\end{tabular}

This article is protected by copyright. All rights reserved. 


\begin{tabular}{|l|l|l|l|l|l|l|}
\hline Ikerasassuaq & 04390 & Cape Farewell & Surface & $60.03^{\circ} \mathrm{N}$ & $43.12^{\circ} \mathrm{W}$ & $88 \mathrm{~m}$ \\
\hline Narsarsuaq & 04270 & Cape Farewell & Upper-Air & $61.15^{\circ} \mathrm{N}$ & $45.43^{\circ} \mathrm{W}$ & $65 \mathrm{~m}$ \\
\hline
\end{tabular}

Table 1) Specifics of the sites along the southeast coast of Greenland where surface and

upper-air observations are collected. Please refer to Figure 1 for the locations of these sites.

\begin{tabular}{|l|l|l|l|l|l|l|}
\hline Flight & Date & Science Aim & $\begin{array}{l}\text { Area of } \\
\text { Operation }\end{array}$ & $\begin{array}{l}\text { Takeoff } \\
\text { UTC }\end{array}$ & $\begin{array}{l}\text { Landing } \\
\text { UTC }\end{array}$ & Dropsondes \\
\hline B268 & 21 February & Easterly Tip Jet & $\begin{array}{l}\text { Cape } \\
\text { Farewell }\end{array}$ & $10: 48$ & $16: 27$ & 12 \\
\hline B271 & 25 February & $\begin{array}{l}\text { Polar Low } \\
\text { interacting with } \\
\text { Greenland }\end{array}$ & Iceland Sea & $10: 35$ & $16: 25$ & 16 \\
\hline B274 & 2 March & Barrier Winds & $\begin{array}{l}\text { Denmark } \\
\text { Strait }\end{array}$ & $11: 07$ & $14: 55$ & 9 \\
\hline B276 & 5 March & Barrier Winds & $\begin{array}{l}\text { Denmark } \\
\text { Strait }\end{array}$ & $11: 20$ & $17: 06$ & 8 \\
\hline B277 & 6 March & Barrier Winds & $\begin{array}{l}\text { Denmark } \\
\text { Strait }\end{array}$ & $10: 27$ & $16: 00$ & 17 \\
\hline B278 & 9 March & $\begin{array}{l}\text { Barrier Winds \& } \\
\text { Air-Sea Interaction }\end{array}$ & $\begin{array}{l}\text { Denmark } \\
\text { Strait }\end{array}$ & $10: 31$ & $15: 11$ & 6 \\
\hline
\end{tabular}

Table 2) Specifics of the GFDex research flights considered in this paper.

\begin{tabular}{|l|c|c|c|c|c|c|c|c|c|}
\hline Stn\# & \multicolumn{7}{|c|}{ Root Mean Square Error $\mathbf{( m ~ s}^{-1}$ ) } & \multicolumn{6}{|c|}{ Correlation Coefficient } & \multicolumn{2}{l|}{ Slope } \\
\hline & $E R A-I$ & $A S R v 1$ & $A S R v 2$ & $E R A-I$ & ASRv1 & ASRv2 & ERA-I & ASRv1 & ASRv2 \\
\hline 04339 & 3.96 & 3.24 & 3.17 & 0.61 & 0.73 & 0.84 & 0.49 & 0.59 & 0.93 \\
\hline 04360 & 4.84 & 4.07 & 2.25 & 0.63 & 0.58 & 0.65 & 1.21 & 2.01 & 1.83 \\
\hline 04373 & 3.65 & 2.42 & 0.9 & 0.62 & 0.86 & 0.98 & 0.28 & 0.64 & 0.96 \\
\hline 04382 & 3.41 & 2.08 & 1.67 & 0.76 & 0.9 & 0.93 & 0.52 & 0.75 & 0.93 \\
\hline 04390 & 3.28 & 2.7 & 1.66 & 0.87 & 0.91 & 0.96 & 0.65 & 0.84 & 1.01 \\
\hline All & 4.82 & 4.18 & 3.2 & 0.74 & 0.82 & 0.92 & 0.5 & 0.73 & 0.94 \\
\hline
\end{tabular}

Table 3) Comparison of the $10 \mathrm{~m}$ wind speed statistics for observations and reanalyses at

DMI stations in southeast Greenland for the period 15 February- 16 March 2007.

This article is protected by copyright. All rights reserved. 


\begin{tabular}{|l|c|c|c|c|c|c|c|c|c|}
\hline Station & \multicolumn{9}{|l|}{$\begin{array}{l}\text { Root Mean Square Error } \\
\left(\mathbf{m ~ s}^{-1}\right)\end{array}$} \\
& $E R A-I$ & ASRv1 & ASRv2 & ERA-I & ASRv1 & ASRv2 & ERA-I & ASRv1 & ASRv2 \\
\hline & 7.19 & 7.46 & 7.62 & 0.5 & 0.43 & 0.43 & 0.4 & 0.28 & 0.34 \\
\hline Ittoqqortoormiit & 5.48 & 4.75 & 3.61 & 0.76 & 0.81 & 0.89 & 0.76 & 0.74 & 0.88 \\
\hline Tasiilaq & 4.17 & 4.06 & 2.33 & 0.83 & 0.85 & 0.95 & 0.81 & 0.92 & 0.92 \\
\hline Narsarsuaq & 5.70 & 5.58 & 5.00 & 0.70 & 0.71 & 0.77 & 0.65 & 0.63 & 0.71 \\
\hline All &
\end{tabular}

Table 4) Comparison statistics between wind speed and corresponding values from the ERA-I,

ASRv1 and ASRv2 for radiosonde stations in the vicinity of southeast Greenland

during the period 15 February- 16 March 2007.

\begin{tabular}{|l|l|l|l|l|l|l|l|l|l|l|}
\hline Flight & \multicolumn{2}{|l|}{ Root Mean Square Error $\mathbf{m ~ s}^{-\mathbf{1}}$ ) } & \multicolumn{2}{l|}{ Correlation Coefficient } & \multicolumn{2}{l|}{ Slope } \\
\hline & ERA-I & ASRv1 & ASRv2 & ERA-I & ASRv1 & ASRv2 & ERA-I & ASRv1 & ASRv2 \\
\hline B268 & 3.27 & 3.75 & 3.34 & 0.87 & 0.84 & 0.89 & 0.76 & 0.56 & 0.90 \\
\hline B271 & 2.90 & 2.86 & 2.64 & 0.80 & 0.82 & 0.85 & 0.78 & 0.74 & 0.83 \\
\hline B274 & 3.12 & 4.27 & 3.33 & 0.90 & 0.81 & 0.89 & 0.77 & 0.68 & 0.79 \\
\hline B276 & 2.12 & 2.06 & 1.92 & 0.89 & 0.90 & 0.91 & 0.77 & 0.78 & 0.77 \\
\hline B277 & 4.56 & 3.19 & 2.81 & 0.75 & 0.86 & 0.90 & 0.64 & 0.70 & 0.80 \\
\hline B278 & 4.08 & 3.00 & 2.34 & 0.59 & 0.75 & 0.81 & 0.87 & 0.63 & 0.78 \\
\hline All & 3.56 & 3.28 & 2.82 & 0.90 & 0.91 & 0.94 & 0.90 & 0.89 & 0.91 \\
\hline
\end{tabular}

Table 5) Comparison statistics between wind speeds and corresponding values from the ERA-I,

ASRv1 and ASRv2 for the dropsondes from the GFDex flights.

This article is protected by copyright. All rights reserved. 


\section{Figure Captions}

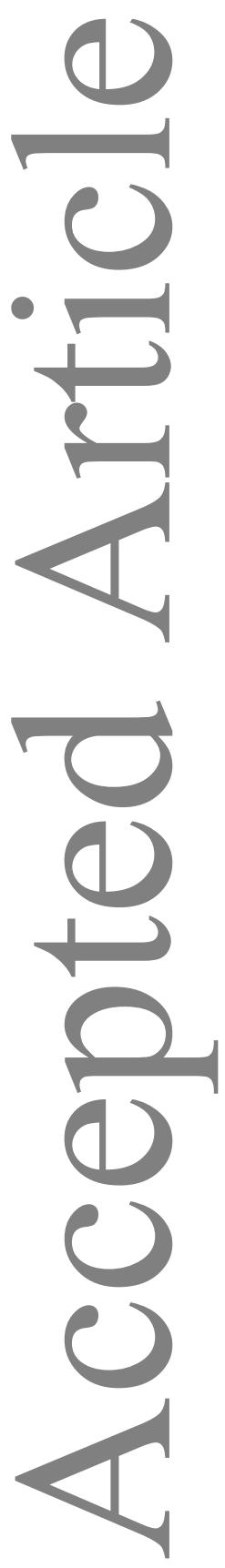

This article is protected by copyright. All rights reserved. 
a) ERAI
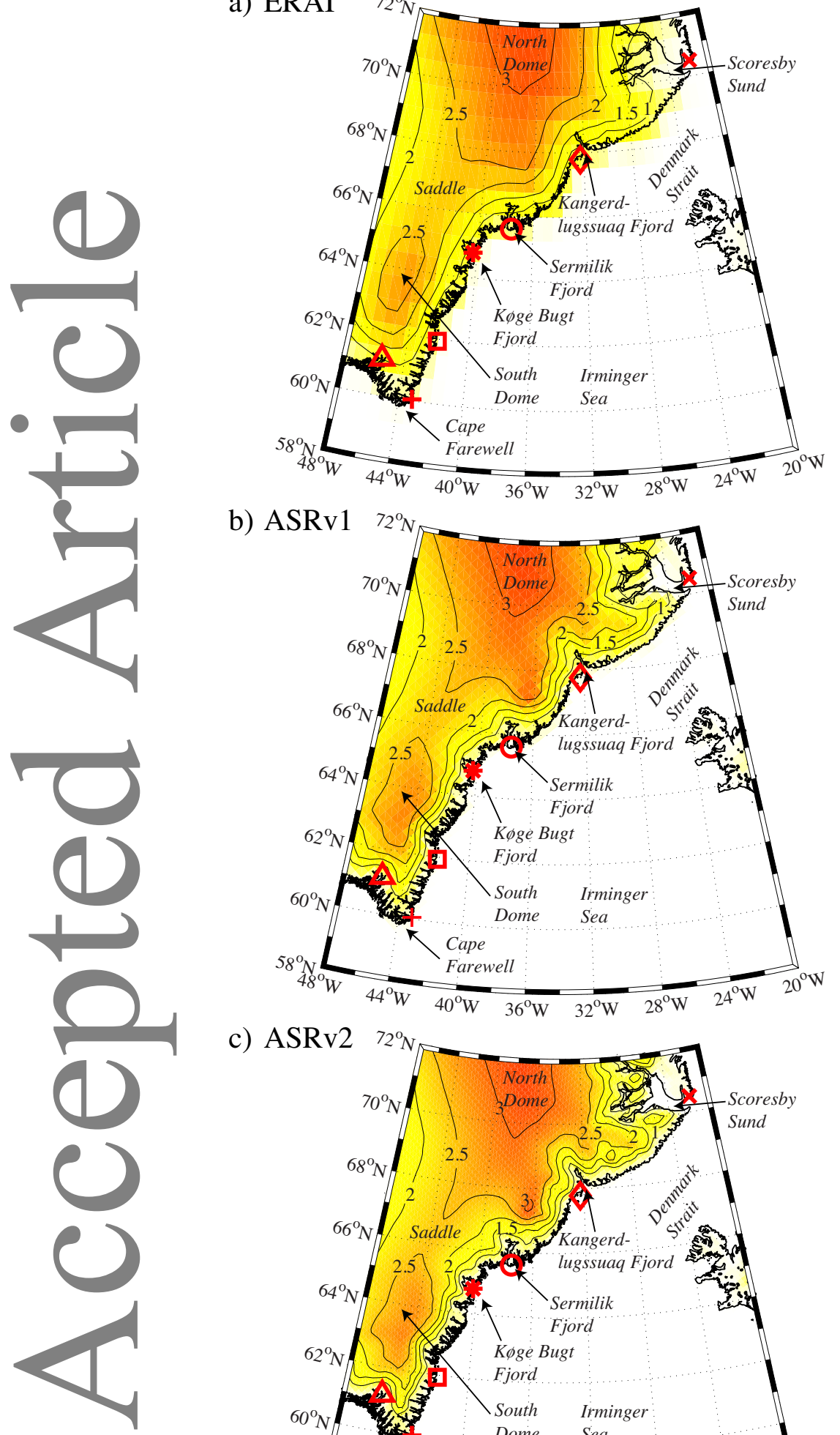

b) ASRv1

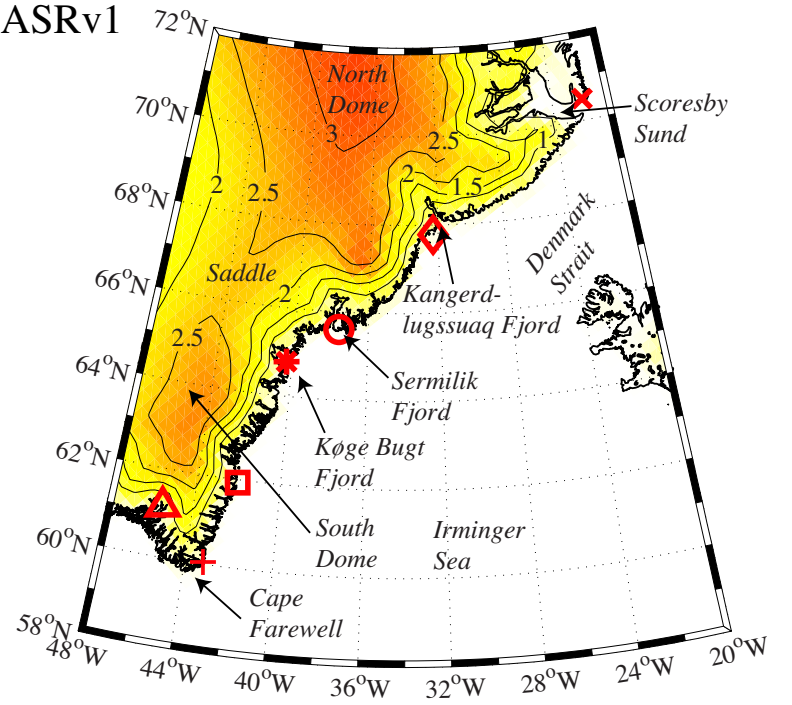

c) ASRv2

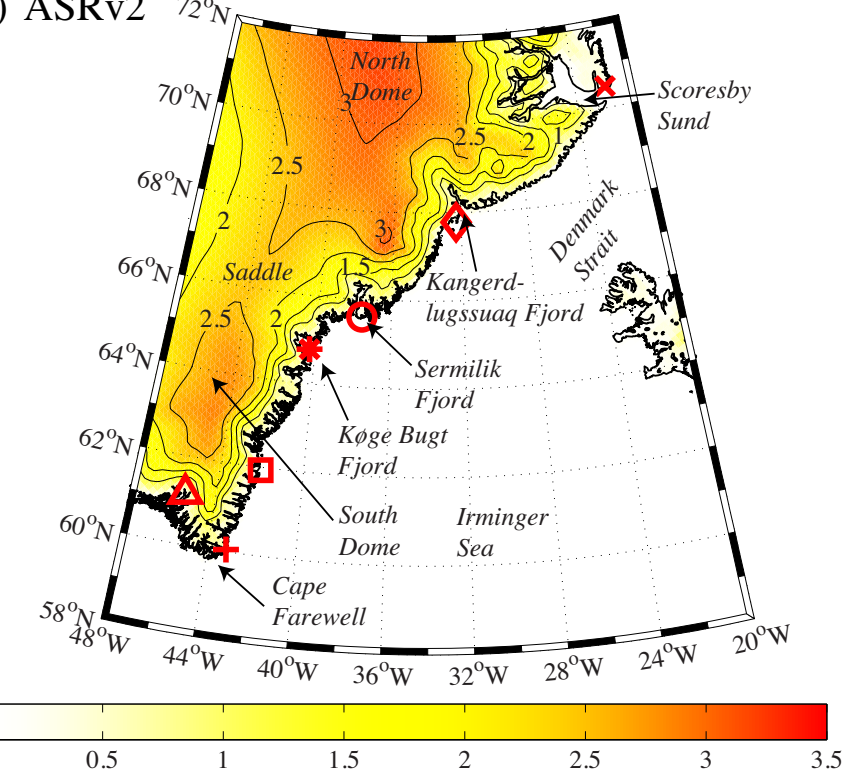

This article is protected by copyright. All rights reserved. 
Figure 1) The topography $(\mathrm{km})$ of southeast Greenland as represented in the: a) ERA-I, b)ASRv1 and c)ASRv2. Placenames of interest are shown. The ' $x$ ', ' $\Delta$ ', ' 0 ', '*', ' $\square$ ', and '+' symbols indicate the locations of the DMI stations (from North to South) $04339,04351,04360,04373,04382$ and 04390 respectively. The ' $x$ ', 'o' and ' $\Delta$ ' symbols indicate the locations of the Ittoqqortoormiit, Tasiilaq and Narsarsuaq radiosonde sites.

This article is protected by copyright. All rights reserved. 
a) ERAI
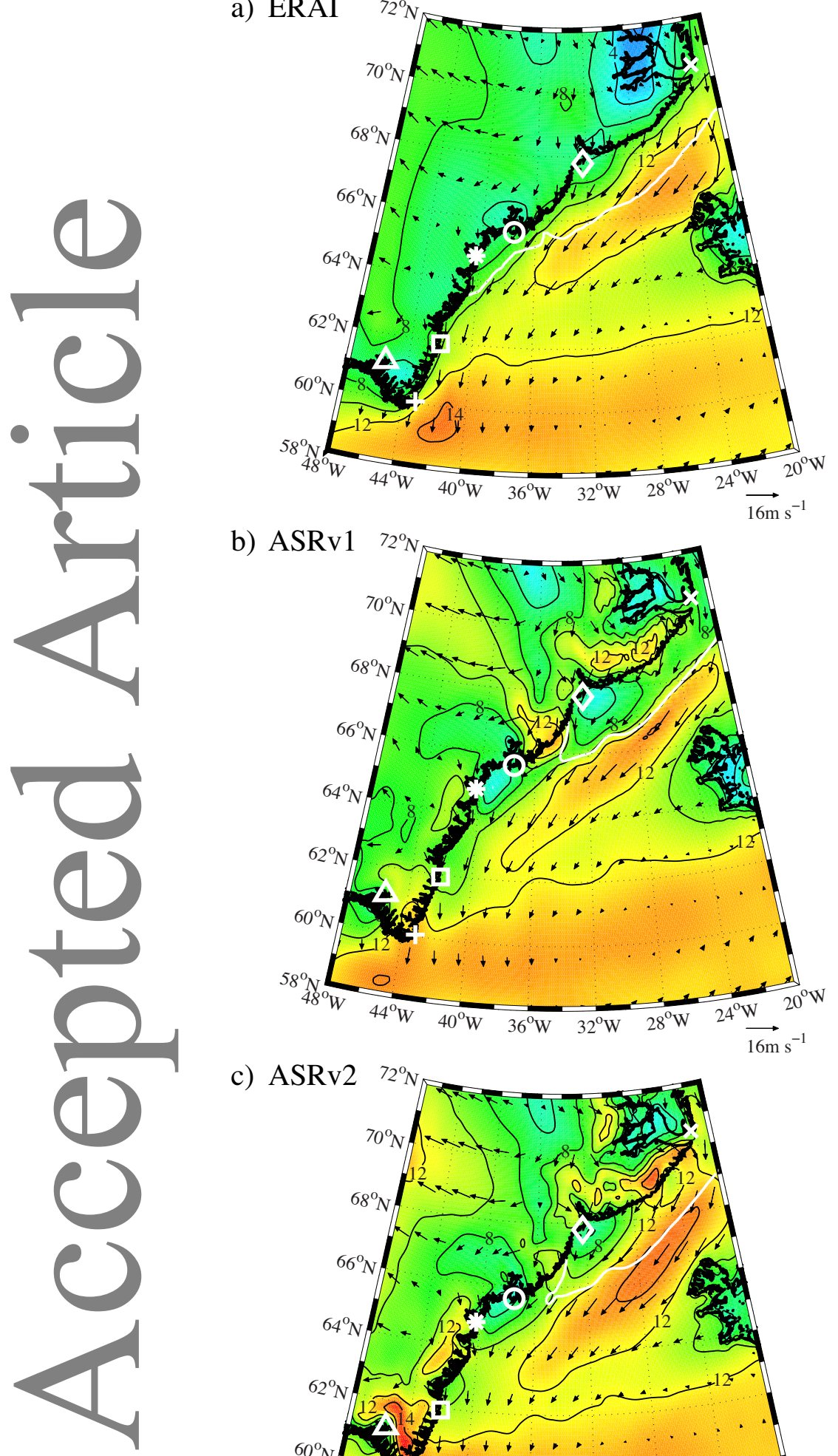

b) ASRv1

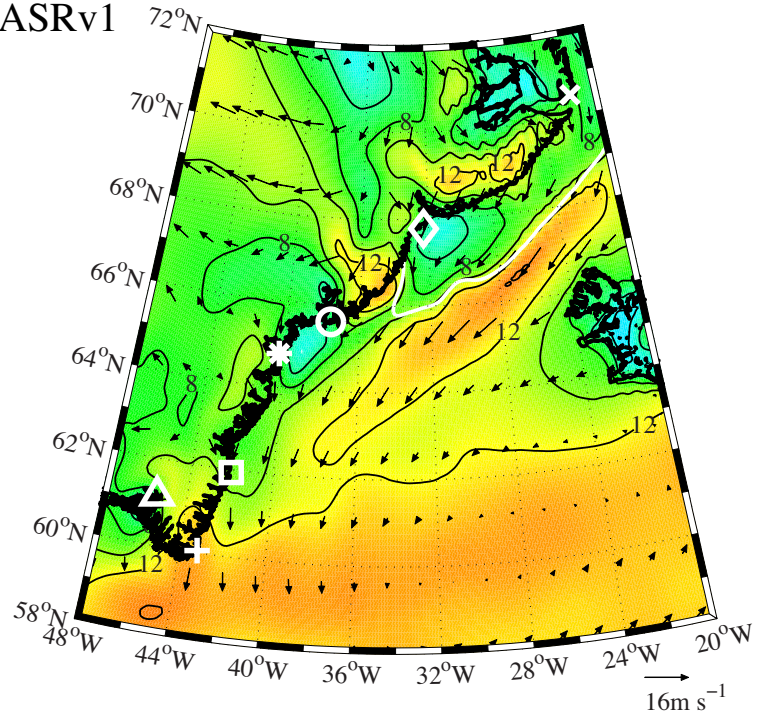

c) ASRv2

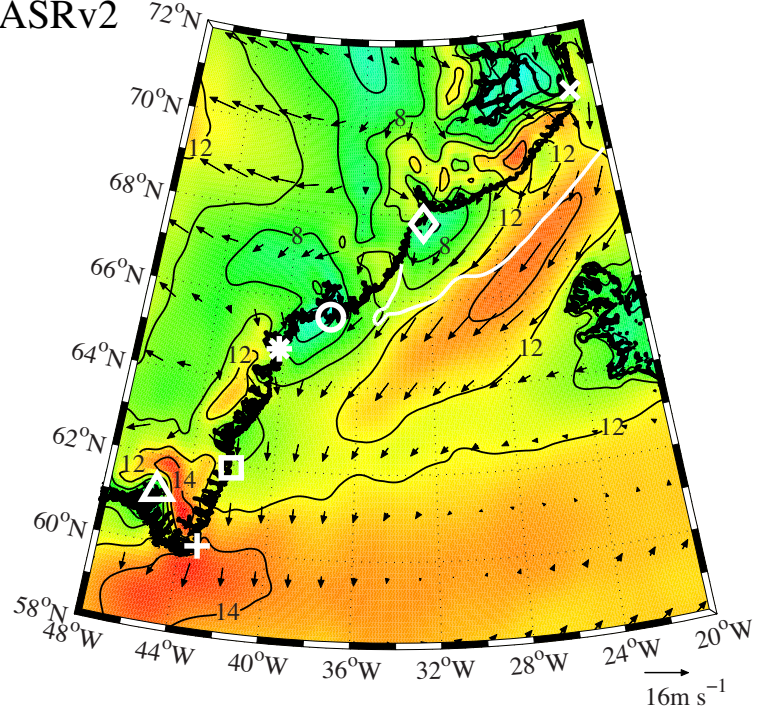

This article is protected by copyright. All rights reserved. 
Figure 2) The mean $10 \mathrm{~m}$ wind (vectors- $\mathrm{m} \mathrm{s}^{-1}$ ) and $10 \mathrm{~m}$ wind speed (shading and contours-m s${ }^{-1}$ ) from the: a)ERA-I, b)ASRv1 and c)ASRv2 for the period 15 February- 16 March 2007. The white curves are the respective 50\% mean sea ice concentration contour. The ' $\mathrm{x}$ ', ' $\mathrm{o}^{\prime}$ ', ' $\mathrm{o}$ ', '*', ' $\square$ ', and '+' symbols indicate the locations of the DMI stations (from North to South) 04339, 04350, 04360, 04373, 04382 and 04390 respectively. The ' $\mathrm{x}$ ', ' $\mathrm{o}$ ' and ' $\Delta$ ' symbols indicate the locations of the Ittoqqortoormiit, Tasiilaq and Narsarsuaq radiosonde sites.

a) DMI 04339 Ittoqqortoormiit

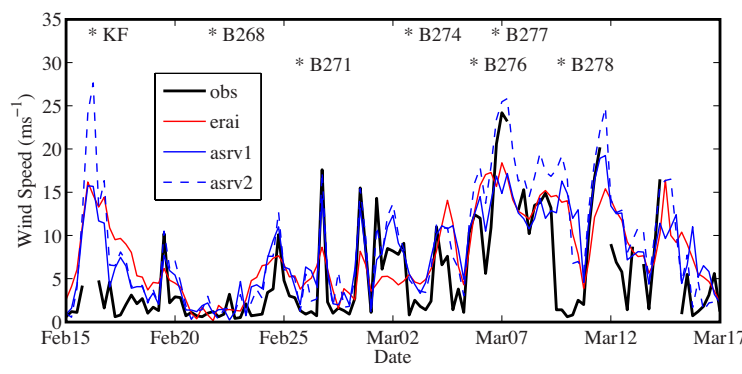

c) DMI 04360 Tasiilaq

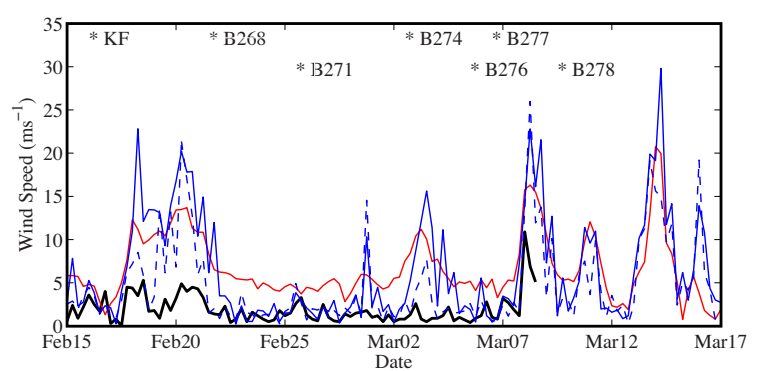

e) DMI 04382 Ikermiuarsuk

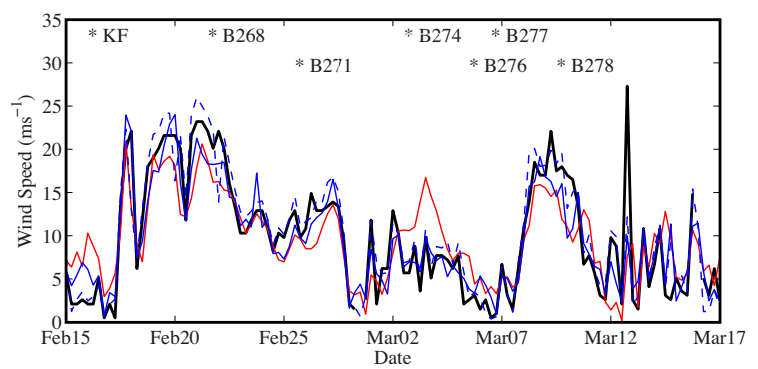

b) DMI 04351 Aputiteeq

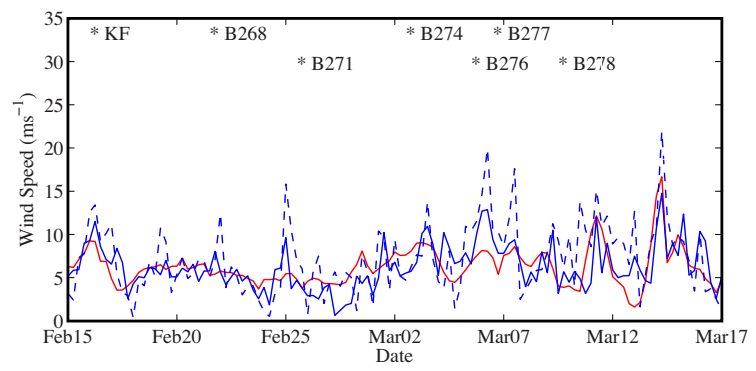

d) DMI 04373 Ikermit

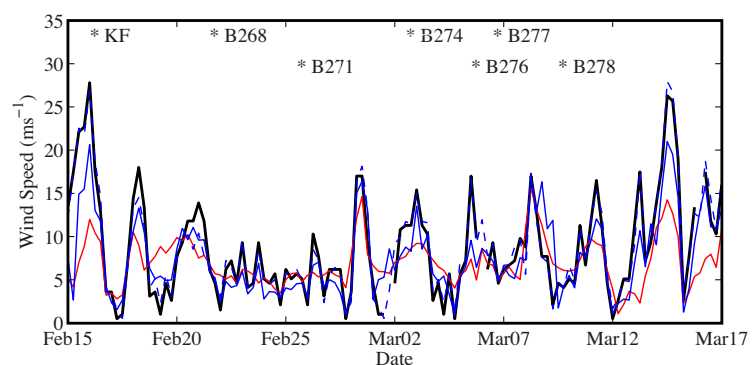

f) DMI 04390 Ikerasassuaq

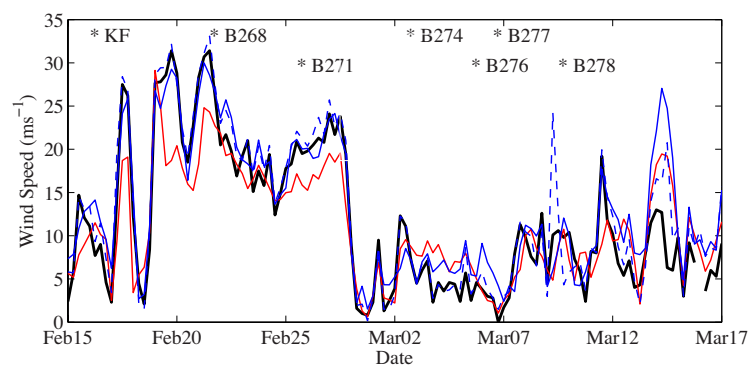

Figure 3) Time series of $10 \mathrm{~m}$ wind speed $\left(\mathrm{m} \mathrm{s}^{-1}\right)$ at the DMI sites: a) $\left.04339, \mathrm{~b}\right)$ 04351, c) 04360, d) 04373 , e) 04382 and f) 04390 during the period 15 February - 16 March 
2007 as represented by observations (black curves) and the ERA-I (red curves), ASRv1 (blue curves) and ASRv2 (dashed blue curves). Note that there are no observations at site 04351 during this period. Also shown is the timing of the katabatic flow event observed at site 04373 (KF) as well as the low-level segments of the GFDex flights (B268,B271,B274, B276, B277 and B278).

This article is protected by copyright. All rights reserved. 


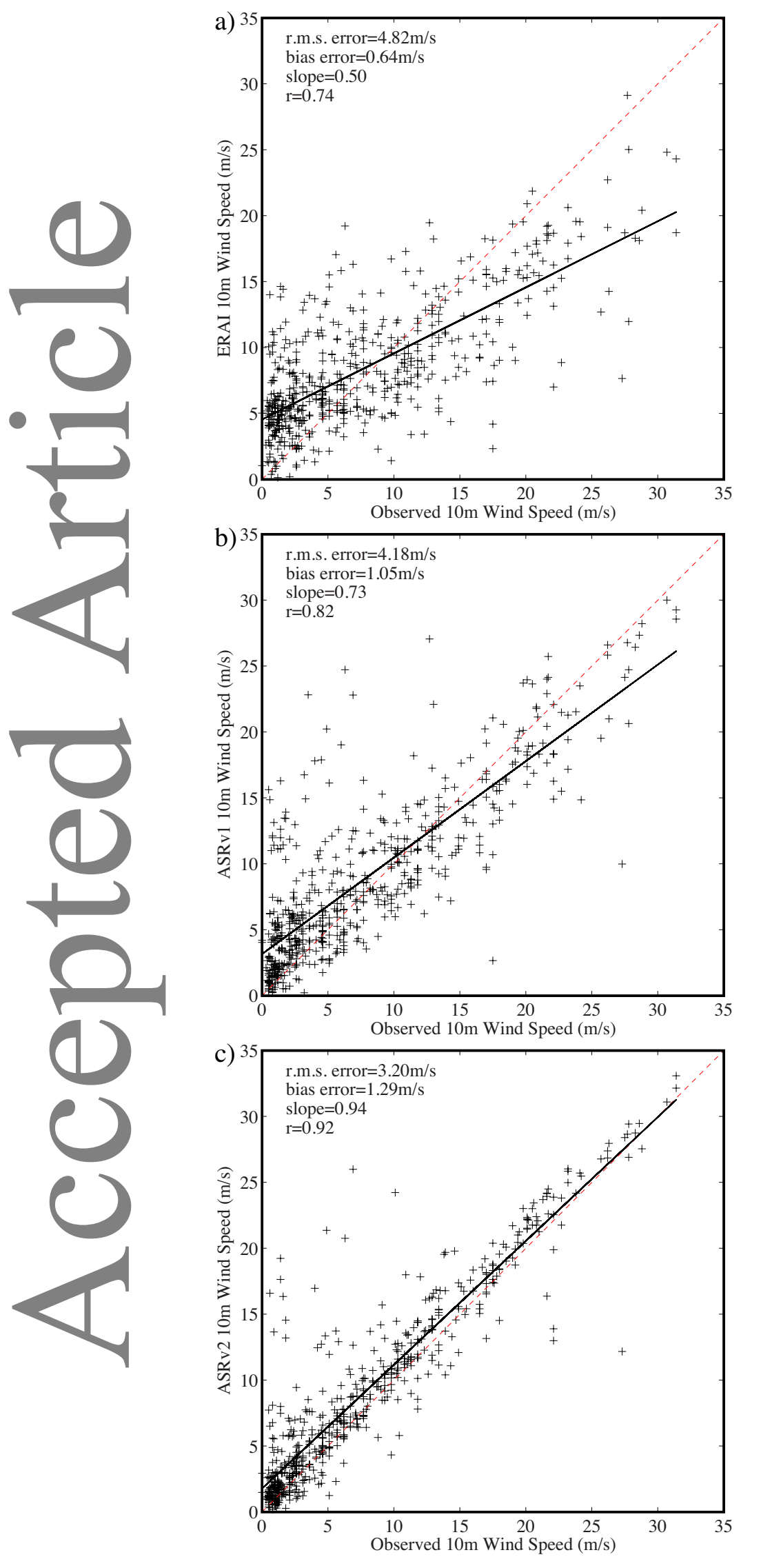

This article is protected by copyright. All rights reserved. 
Figure 4 Scatterplot of the $10 \mathrm{~m}$ wind speeds $\left(\mathrm{m} \mathrm{s}^{-1}\right)$ from DMI stations and corresponding values for the period 15 February- 16 March 2007 from the: (a) ERA-I, (b) ASRv1 and (c) ASRv2. Red dashed lines are 1:1 plots. Error statistics for each fit are shown. 
Figure 5) Comparison of the mean vertical profile of wind speed $\left(\mathrm{m} \mathrm{s}^{-1}\right)$ for the period 15 February-16 March 2007 and corresponding profiles from the ERA-I, ASRv1 and ASRv2 for the radiosonde stations at: (a) Ittoqqortoormiit, (b) Tasiilaq and (c) Narsarsuaq.

This article is protected by copyright. All rights reserved. 

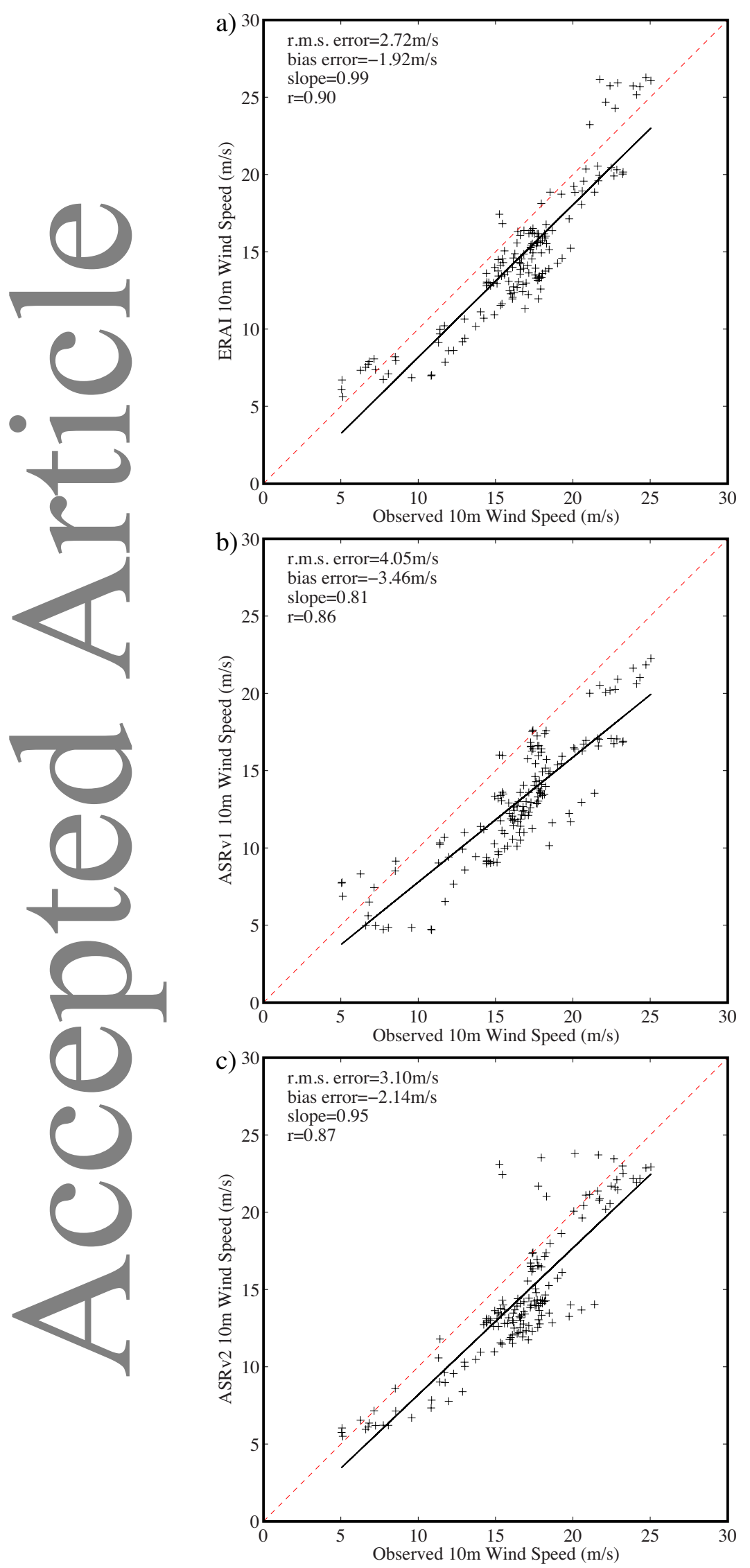

This article is protected by copyright. All rights reserved. 
Figure 6) Scatterplot of the $10 \mathrm{~m}$ wind speeds $\left(\mathrm{m} \mathrm{s}^{-1}\right)$ from GFDex low-level flight legs and corresponding values from the: (a) ERA-I, (b) ASRv1 and (c) ASRv2. Red dashed lines are 1:1 plots. Error statistics for each fit are shown.

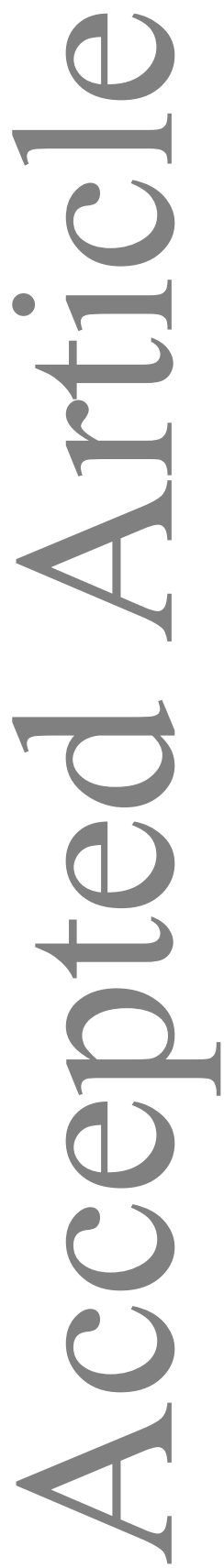

This article is protected by copyright. All rights reserved. 
Figure 7) Comparison of observed dropsonde wind speeds ( $\mathrm{m} \mathrm{s}^{-1}$ ) from GFDex topographic flow distortion flights and corresponding values from the: (a) ERA-I, (b) ASRv1 and (c) ASRv2. Red dashed lines are 1:1 plots. Error statistics for each fit are shown. 

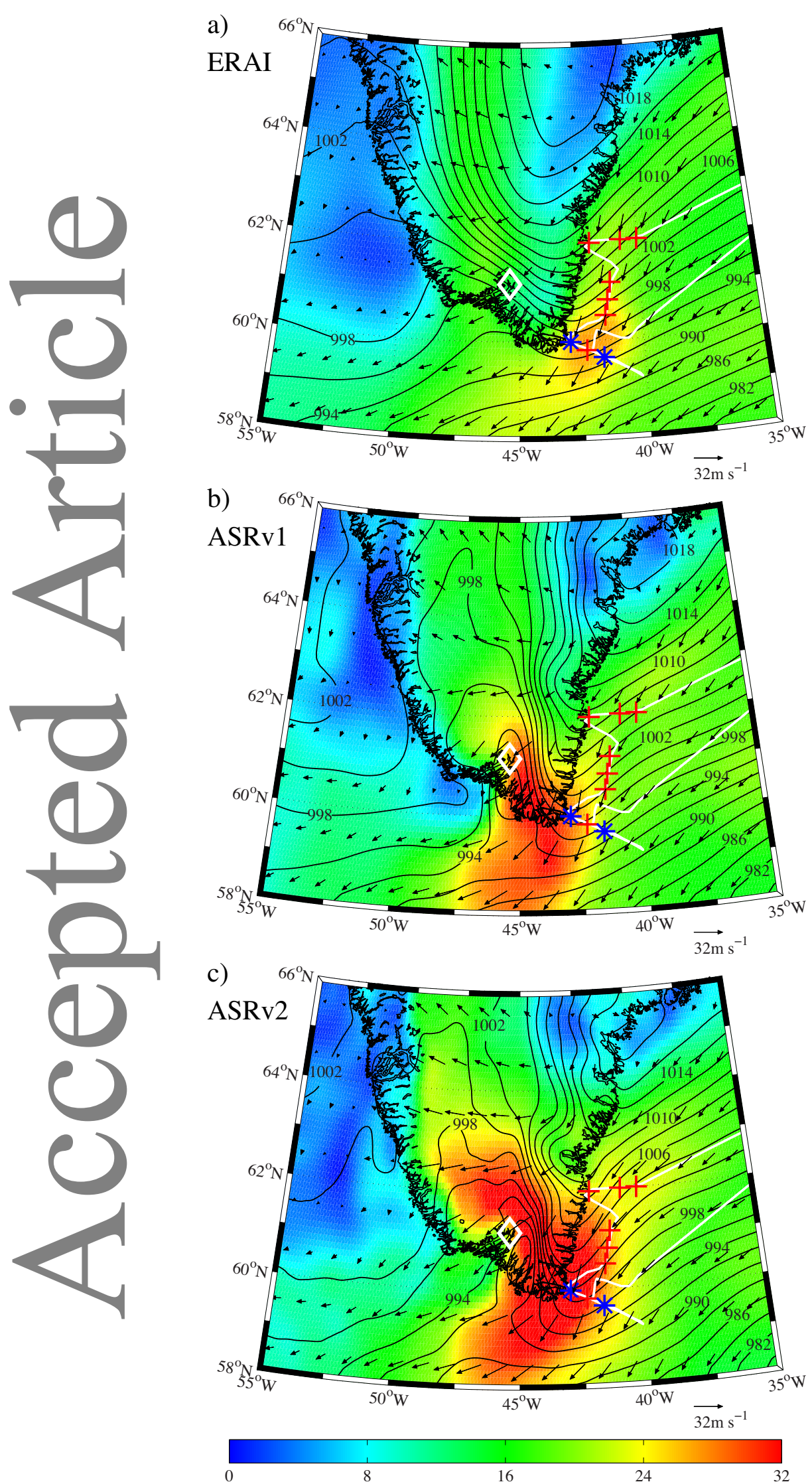

This article is protected by copyright. All rights reserved. 
Figure 8) Atmospheric circulation during the B268 GFDex mission at 12UTC on 21 February 2007. The sea-level pressure (mb-contours), $10 \mathrm{~m}$ wind ( $\mathrm{m} \mathrm{s}^{-1}$-vectors) and $10 \mathrm{~m}$ wind speed ( $\mathrm{m} \mathrm{s}^{-1}$-shading) as represented in the: (a) ERA-I, (b) ASRv1 and (c) ASRv2. The FAAM flight plan is is shown as the white curve along with the locations of the dropsondes, indicated by the '+' and '*', that were launched. The site of the Narsarsuaq radiosonde station in indicated by the ' $\diamond$ '. Data from the dropsondes indicated by the '*' and the Narsarsuaq radiosonde are shown in Figure 9.

This article is protected by copyright. All rights reserved. 
Figure 9) Vertical profile of wind speed $\left(\mathrm{m} \mathrm{s}^{-1}\right)$ on 21 February 2007 during the B268 easterly tip jet flight from: a) the 12 UTC Narsarsuaq radiosonde, b) the 13:21 UTC dropsonde \# 9 and c) the 13:24 UTC dropsonde \#11 along with the corresponding wind speeds from the ERA-I, ASRv1 and ASRv2.

This article is protected by copyright. All rights reserved. 
Figure 10) Atmospheric circulation during the B277 GFDex mission at 15 UTC on 6 March 2007. The sea-level pressure (mb-contours), $10 \mathrm{~m}$ wind ( $\mathrm{m} \mathrm{s}^{-1}$-vectors) and $10 \mathrm{~m}$ wind speed ( $\mathrm{m} \mathrm{s}^{-1}$-shading) as represented in the: (a) ERA-I, (b) ASRv1 and (c) ASRv2. The FAAM flight plan is shown as the white curve along with the locations of the dropsondes, indicated by the '+' and '*', that were launched. The $50 \%$ sea ice concentration profile from the respective dataset is indicated by the thick blue contour. The site of the Ittoqqortoormiit radiosonde station in indicated by the ' $\Delta$ '. Data from the dropsondes indicated by the ' $*$ ' and the Narsarsuaq radiosonde are shown in Figure 11. 
Figure 11) Vertical profile of wind speed $\left(\mathrm{m} \mathrm{s}^{-1}\right)$ on 6 March 2007 during the B277 barrier wind flight from: a) the 12 UTC Ittoqqortoormiit radiosonde, b) the 14:09 UTC dropsonde \# 3 and c) the 14:59 UTC dropsonde \#12 along with the corresponding wind speeds from the ERA-I, ASRv1 and ASRv2.

This article is protected by copyright. All rights reserved. 
Figure 12) Atmospheric circulation during the Køge Bugt Fjiord katabatic flow event at 00 UTC on 16 February 2007. The sea-level pressure (mb-contours), $10 \mathrm{~m}$ wind ( $\mathrm{m} \mathrm{s}^{-1}$-vectors) and $10 \mathrm{~m}$ wind speed ( $\mathrm{m} \mathrm{s}^{-1}$-shading) as represented in the: (a) ERA-I, (b) ASRv1 and (c) ASRv2. The 50\% sea ice concentration profile from the respective dataset is indicated by the thick blue contour. The site of the DMI station that observed the event is indicated by the ' 0 '.

This article is protected by copyright. All rights reserved. 


\section{References}

Bromwich, D. H., A. B. Wilson, L.-S. Bai, G. W. K. Moore, and P. Bauer, 2015: A comparison of the regional Arctic System Reanalysis and the global ERA-Interim Reanalysis for the Arctic. Quarterly Journal of the Royal Meteorological Society.

Condron, A., and I. A. Renfrew, 2013: The impact of polar mesoscale storms on northeast Atlantic Ocean circulation. Nature Geoscience, 6, 34-37.

Dee, D. P., and Coauthors, 2011: The ERA-Interim reanalysis: configuration and performance of the data assimilation system. Quarterly Journal of the Royal Meteorological Society, 137, 553-597.

Doyle, J. D., and M. A. Shapiro, 1999: Flow response to large-scale topography: the Greenland tip jet. Tellus Series a-Dynamic Meteorology and Oceanography, 51, 728-748.

Dumont, M., and Coauthors, 2014: Contribution of light-absorbing impurities in snow to Greenland/'s darkening since 2009. Nature Geosci, 7, 509-512.

DuVivier, A. K., and J. J. Cassano, 2013: Evaluation of WRF Model Resolution on Simulated Mesoscale Winds and Surface Fluxes near Greenland. Monthly Weather Review, 141, 941-963.

Ebita, A., and Coauthors, 2011: The Japanese 55-year Reanalysis: An Interim Report. SOLA, 7, 149-152.

Haine, T. W. N., S. Zhang, G. W. K. Moore, and I. A. Renfrew, 2009: On the impact of high-resolution, high-frequency meteorological forcing on Denmark Strait ocean circulation. Quarterly Journal of the Royal Meteorological Society, 135, 20672085.

Hamilton, K., 2008: Numerical resolution and modeling of the global atmospheric circulation: A review of our current understanding and outstanding issues. 7-27 pp.

Harden, B. E., and I. A. Renfrew, 2012: On the spatial distribution of high winds off southeast Greenland. Geophysical Research Letters, 39.

Harden, B. E., I. A. Renfrew, and G. N. Petersen, 2011: A Climatology of Wintertime Barrier Winds off Southeast Greenland. Journal of Climate, 24, 4701-4717.

Harden, B. E., F. Straneo, and D. A. Sutherland, 2014: Moored observations of synoptic and seasonal variability in the East Greenland Coastal Current. Journal of Geophysical Research: Oceans, 119, 8838-8857.

Heinemann, G., and T. Klein, 2002: Modelling and observations of the katabatic flow dynamics over Greenland. Tellus Series a-Dynamic Meteorology and Oceanography, 54, 542-554.

Hines, K. M., D. H. Bromwich, L. Bai, C. M. Bitz, J. G. Powers, and K. W. Manning, 2015: Sea Ice Enhancements to Polar WRF. Monthly Weather Review, 143, 23632385.

Howat, I. M., Y. Ahn, I. Joughin, M. R. van den Broeke, J. T. M. Lenaerts, and B. Smith, 2011: Mass balance of Greenland's three largest outlet glaciers, 2000-2010. Geophysical Research Letters, 38.

Jung, T., S. Serrar, and Q. Wang, 2014: The oceanic response to mesoscale atmospheric forcing. Geophysical Research Letters, 41, 1255-1260. 
Kinter, J. L., and Coauthors, 2012: Revolutionizing Climate Modeling with Project Athena: A Multi-Institutional, International Collaboration. Bulletin of the American Meteorological Society, 94, 231-245.

Magaldi, M. G., and T. W. N. Haine, 2015: Hydrostatic and non-hydrostatic simulations of dense waters cascading off a shelf: The East Greenland case. Deep-Sea Research Part I-Oceanographic Research Papers, 96, 89-104.

Manley, G., 1938: Meteorological observations of the British East Greenland expedition, 1935-36, at Kangerdlugssuak, $68^{\circ} 10^{\prime}$ N., $31^{\circ} 44^{\prime}$ W. Quarterly Journal of the Royal Meteorological Society, 64, 253-276.

Moore, G. W. K., 2003: Gale force winds over the Irminger Sea to the east of Cape Farewell, Greenland. Geophysical Research Letters, 30.

— 2012: A new look at Greenland flow distortion and its impact on barrier flow, tip jets and coastal oceanography. Geophysical Research Letters, 39.

Moore, G. W. K., and I. A. Renfrew, 2005: Tip jets and barrier winds: A QuikSCAT climatology of high wind speed events around Greenland. Journal of Climate, 18, 3713-3725.

Moore, G. W. K., R. S. Pickart, and I. A. Renfrew, 2011: Complexities in the climate of the subpolar North Atlantic: a case study from the winter of 2007. Quarterly Journal of the Royal Meteorological Society, 137, 757-767.

Moore, G. W. K., I. A. Renfrew, B. E. Harden, and S. H. Mernild, 2015: The impact of resolution on the representation of southeast Greenland barrier winds and katabatic flows. Geophysical Research Letters, 42, 3011-3018.

Oltmanns, M., F. Straneo, G. W. K. Moore, and S. H. Mernild, 2014: Strong Downslope Wind Events in Ammassalik, Southeast Greenland. Journal of Climate, 27, 977993.

Oltmanns, M., F. Straneo, H. Seo, and G. W. K. Moore, 2015: The Role of Wave Dynamics and Small-Scale Topography for Downslope Wind Events in Southeast Greenland. Journal of the Atmospheric Sciences, 72, 2786-2805.

Outten, S. D., I. A. Renfrew, and G. N. Petersen, 2009: An easterly tip jet off Cape Farewell, Greenland. II: Simulations and dynamics. Quarterly Journal of the Royal Meteorological Society, 135, 1934-1949.

Petersen, G. N., and I. A. Renfrew, 2009: Aircraft-based observations of air-sea fluxes over Denmark Strait and the Irminger Sea during high wind speed conditions. Quarterly Journal of the Royal Meteorological Society, 135, 2030-2045.

Petersen, G. N., I. A. Renfrew, and G. W. K. Moore, 2009: An overview of barrier winds off southeastern Greenland during the Greenland Flow Distortion experiment. Quarterly Journal of the Royal Meteorological Society, 135, 1950-1967.

Pickart, R. S., M. A. Spall, M. H. Ribergaard, G. W. K. Moore, and R. F. Milliff, 2003: Deep convection in the Irminger Sea forced by the Greenland tip jet. Nature, 424, 152-156.

Rasmussen, L., 1989: Greenland Winds and Satellite Imagery. Vejret-Danish Meteorological Society, 32-37.

Renfrew, I. A., S. D. Outten, and G. W. K. Moore, 2009a: An easterly tip jet off Cape Farewell, Greenland. I: Aircraft observations. Quarterly Journal of the Royal Meteorological Society, 135, 1919-1933.

This article is protected by copyright. All rights reserved. 
Renfrew, I. A., G. N. Petersen, D. A. J. Sproson, G. W. K. Moore, H. Adiwidjaja, S. Zhang, and R. North, 2009b: A comparison of aircraft-based surface-layer observations over Denmark Strait and the Irminger Sea with meteorological analyses and QuikSCAT winds. Quarterly Journal of the Royal Meteorological Society, 135, 2046-2066.

Renfrew, I. A., and Coauthors, 2008: The Greenland flow distortion experiment. Bulletin of the American Meteorological Society, 89, 1307-1324.

Sabine, C. L., and Coauthors, 2004: The Oceanic Sink for Anthropogenic CO2. Science, 305, 367-371.

Saha, S., and Coauthors, 2010: THE NCEP Climate Forecast System Reanalysis. Bulletin of the American Meteorological Society, 91, 1015-1057.

Sampe, T., and S. P. Xie, 2007: Mapping high sea winds from space: A global climatology. Bulletin of the American Meteorological Society, 88, 1965-+.

Silva-Sánchez, N., J. E. Schofield, T. M. Mighall, A. Martínez Cortizas, K. J. Edwards, and I. Foster, 2015: Climate changes, lead pollution and soil erosion in south Greenland over the past 700 years. Quaternary Research, 84, 159-173.

Skamarock, W. C., 2004: Evaluating mesoscale NWP models using kinetic energy spectra. Monthly Weather Review, 132, 3019-3032.

Skamarock, W. C., and Coauthors, 2008: A description of the Advanced Research WRF Version 3.

Smith, R. B., 1982: Synoptic Observations and Theory of Orographically Disturbed Wind and Pressure. Journal of the Atmospheric Sciences, 39, 60-70.

Straneo, F., and P. Heimbach, 2013: North Atlantic warming and the retreat of Greenland's outlet glaciers. Nature, 504, 36-43.

Straneo, F., and C. Cenedese, 2015: The Dynamics of Greenland's Glacial Fjords and Their Role in Climate. Annual Review of Marine Science, 7, 89-112.

Våge, K., R. S. Pickart, G. W. K. Moore, and M. H. Ribergaard, 2008: Winter mixed layer development in the central irminger sea: The effect of strong, intermittent wind events. Journal of Physical Oceanography, 38, 541-565. 